\title{
Satirn as pesticide inhibitor for the corrosion of the galvanized iron in wastewater and its biological effect on Escherichia coli
}

\begin{abstract}
Satirn is a type of the pesticides has been evaluated as green inhibitor for the corrosion of the galvanized iron in saline solution which was investigated by chemical and electrochemical measurements. The results of polarization showed that satirn acts as mixed type inhibitor. Inhibition was found to increase with the increase of satirn concentration reaching to approximately $90 \%$ at $250 \mathrm{ppm}$. The inhibitive action was discussed by the adsorption of a stable complex on the metal surface. The adsorption of satirn on the metal surface obeys Temkin adsorption isotherm. Satirn has a slightly effect on Escherichia Coli and can be applied safely in sanitation plants.
\end{abstract}

Keywords: corrosion inhibition, satirn, galvanized iron, saline solution.

\section{INTRODUCTION}

Galvanized iron is widely used in industries due to its good mechanical property. The investigation of corrosion of galvanized iron is always a subject of high theoretical as well as practical interest. Chloride and sulfide in aqueous media are particularly aggressive and accelerate corrosion. The use of inhibitors is one of the most practical methods for protection against corrosion [1]. Among numerous inhibitors that have been tested and applied industrially as corrosion inhibitors, those that are non-toxic or low-toxic are now far more strategic than in the recent past. In the $21^{\text {st }}$ century, the research in the field of green or eco-friendly corrosion inhibitors has been addressed toward the goal of using cheep, effective compounds at low or zero environmental impact. Plant extract is low-cost and environmental safe, that which is the main advantage of it. Many synthetic compounds give good anticorrosive activity, most of them are highly toxic to both human beings and the environment [2], and they are often expensive and non-biodegradable. Low-grade gram flour, natural honey, onion, potato, gelatin, plant roots, and flowers gums have been reported as good inhibitors. However, most of them have been tested on steel and nickel sheets. So the use of green inhibitor play an important role in the corrosion of the metals, that it acts as an incredibly rich source of naturally synthesized chemical compounds that are biodegradable in nature and can be extracted by simple procedures with low cost [3].

Author's address: ${ }^{1}$ Department of Chemistry, Faculty of Science, El-Mansoura University, El-Mansoura-35516, Egypt, ${ }^{2}$ Department of Agric. Chemistry, Faculty of Agriculture, Mansoura University, Mansoura, Egypt, ${ }^{3}$ Lab manager in Talkha sanitation plant, water and waste water company, Dakahlia, Egypt, ${ }^{4}$ Nile Higher Institute for Engineering and Technology, El-Mansoura, Egypt

Received for Publication: 11. 09. 2014.

Accepted for Publication: 23. 11. 2014.
Due to the chemical structure and chemical behavior, an inorganic compound must be able to oxidize the metal, forming a passive layer on its surface. On the other hand, a molecule of an organic compound must have the ability to act as a corrosion inhibitor. Among these, the molecule may have a large structure, double bonds, an active center or group, etc. These features give the molecule ability to cover a large area of a metal surface with a firmly attached film [4].

The aim of this work is to study: The effect of using satirn pesticide as a green corrosion inhibitor for the galvanized iron in sulfide polluted salt water using different techniques and ii) The biological effect of satirn pesticide on the activity of Escherichia Coli.

\section{EXPERIMENTAL}

\subsection{Material composition of the sample}

The material used is galvanized iron which provided from Talkha sanitation plant, Egypt. The chemical composition (weight \%): $0.008 \% \mathrm{Si}, 0.257 \%$ $\mathrm{Mn}, 1.942 \% \mathrm{Zn}$ and the remainder is iron.

\subsection{Preparation of the inhibitor}

Stock solution of $1000 \mathrm{ppm}$ satirn was prepared by dissolving $2 \mathrm{ml}$ of a liquid satirn from its bottle of a concentration $50 \%$ in 1 litter of bidistilled water.

\subsubsection{Chemical structures of Satirn}

Chemical structures of Satirn is given in the following scheme:

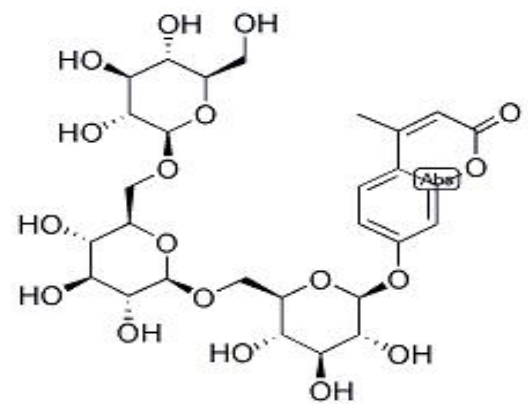




\subsection{Preparation of bacterial agriculture media}

Suspend $50 \mathrm{~g}$ of the medium in 1 litter of bidistilled water and dissolve it by heating. Sterilize in autoclave at $121^{\circ} \mathrm{C}$ for $15 \mathrm{~min}$. Cool to $45-50^{\circ} \mathrm{C}$, mix well and dispense into plates. Allow the plates to solidify. The prepared medium should be at 8$15^{\circ} \mathrm{C}$. The color is violet-red.

\subsection{Solutions}

The aggressive solutions of $3.5 \% \mathrm{NaCl}$ and 16 ppm Na2S was prepared by dissolving the required amount of salts in bidistilled water. All chemicals were analytical grade reagents. The experiments were carried out under non-stirred and naturally aerated conditions. The addition of the extract did not change the $\mathrm{pH}$ of the aggressive media.

\subsection{Electrochemical procedure}

For electrochemical measurements, the sheets were welded with $\mathrm{Cu}$-wire for electrical connection and mounted into glass tubes of appropriate diameter using Araldite to offer an active surface of (1 $\mathrm{cm}^{2}$ ) geometric area to contact the test solution. Prior to each experiment, these sheets were first abraded with different grades of emery papers (800 to 1200 grades), washed with bidistilled water, degreased with absolute ethanol and then dried. A conventional electrochemical cell of capacity 100 $\mathrm{ml}$ was used containing three compartments for working, platinum foil counter $\left(1 \mathrm{~cm}^{2}\right)$ and saturated calomel electrode (SCE) as reference electrode. The measurements were carried out in aerated non-stirred $3.5 \% \mathrm{NaCl}$ with $16 \mathrm{ppm}$ sulfide in the presence of various concentrations of the satirn, as environmentally-friendly corrosion inhibitor. For each run, a freshly prepared solution as well as a cleaned set of electrodes was used. Each run was carried out in aerated stagnant solutions at the required temperature, using a water thermostat. The potentiodynamic polarization curves were carried out at a scan rate of $1 \mathrm{mV} \mathrm{s}^{-1}$ starting from $-1.7 \mathrm{~V}$ up to $-0.1 \mathrm{~V}(\mathrm{SCE})$. Before polarization, the open circuit potential of the working electrode was measured as a function of time during $\mathbf{3 0} \mathrm{min}$, the time necessary to reach a quasi-stationary value for the open-circuit potential. Impedance measurements were carried out using AC signals of amplitude 5 $\mathrm{mV}$ peak to peak at the open-circuit potential in the frequency range $100 \mathrm{kHz}$ and $0.2 \mathrm{~Hz}$. All impedance measurements were recorded at open circuit potential (OCP) after immersion the electrode for 30 minutes in the test solution. Electrochemical frequency modulation was carried out using two frequencies 2 and $5 \mathrm{~Hz}$. The base frequency was $0.1 \mathrm{~Hz}$, so the waveform repeats after 1s. The Intermodulation spectra contain current responses assigned for harmonical and intermodulation current peaks. The larger peaks were used to calculate the corrosion current density ( $\mathrm{i}_{\text {corr }}$ ), the Tafel slopes $\left(\beta_{\mathrm{c}}\right.$ and $\left.\beta_{\mathrm{a}}\right)$ and the causality factors CF2\&CF3 $[5,6]$.

All electrochemical experiments were carried out using Potentiostat/Galvanostat/Zra analyzer (Gamry PCl300/4). A personal computer with DC 105 software for polarization, EIS300 software for impedance, EFM140 software for electrochemical frequency modulation and Echem Analyst 5.21 was used for data fitting and calculating.

\section{RESULTS AND DISCUSSION}

\subsection{Weight loss measurements}

The used inhibitor was tested by six different concentrations and their corresponding corrosion rate with $\%$ protection efficiency $(\% \mathrm{IE})$ data at different temperature $\left(25-40^{\circ} \mathrm{C}\right)$ are presented in Table 1. In figure1 give the weight loss-time curves for the corrosion of galvanized iron in $3.5 \% \mathrm{NaCl}$ and $16 \mathrm{ppm} \mathrm{Na}_{2} \mathrm{~S}$ solutions in the absence and presence of satirn at $25-40^{\circ} \mathrm{C}$. From the experimental data of the weight loss measurements, the \% IE was calculated from Eq. (1):

$$
\% I E=100\left[1-W_{2} / W_{1}\right]
$$

where $W_{1}$ and $W_{2}$ are the weight losses in the absence and presence of satirn, respectively. From Table 1 we found by increasing the concentration of the satirn the \% IE increases, and by raising the temperature the value of \% IE decreases [7]. This behavior can be attributed to the increase of the surface coverage due to the physical adsorption of satirn on the metal surface. The results show the great effect of satirn on the corrosion of the galvanized iron in $3.5 \% \mathrm{NaCl}$ and $16 \mathrm{ppm} \mathrm{Na}_{2} \mathrm{~S}(250$ ppm yield $90.7 \% \mathrm{IE})$.

Table 1- Effect of satirn concentrations on weight loss $\left(\mathrm{mg} \mathrm{cm}^{-2}\right)$ and inhibition efficiency (\% IE) of galvanized iron in sulfide polluted salt water at different temperatures

\begin{tabular}{|c|c|c|c|c|c|c|c|c|}
\hline \multirow{2}{*}{$\begin{array}{c}\text { Conc. } \\
\text { ppm }\end{array}$} & \multicolumn{2}{|c|}{$25^{\circ} \mathrm{C}$} & \multicolumn{2}{c|}{$30^{\circ} \mathrm{C}$} & \multicolumn{2}{c|}{$35^{\circ} \mathrm{C}$} & \multicolumn{2}{c|}{$40^{\circ} \mathrm{C}$} \\
\cline { 2 - 9 } & $\begin{array}{c}\text { Weight loss } \\
\mathrm{mg} \mathrm{cm}^{-2}\end{array}$ & $\% \mathrm{IE}$ & $\begin{array}{c}\text { Weight loss } \\
\mathrm{mg} \mathrm{cm}^{-2}\end{array}$ & $\% \mathrm{IE}$ & $\begin{array}{c}\text { Weight loss } \\
\mathrm{mg} \mathrm{cm}^{-2}\end{array}$ & $\% \mathrm{IE}$ & $\begin{array}{c}\text { Weight loss } \\
\mathrm{mg} \mathrm{cm}^{-2}\end{array}$ & $\% \mathrm{IE}$ \\
\hline Blank & 0.70710 & ----- & 0.73230 & ------ & 0.77020 & ------ & 0.833330 & ------- \\
\hline 50 & 0.34520 & 51.2 & 0.44050 & 39.9 & 0.50000 & 35.1 & 0.64630 & 22.4 \\
\hline 100 & 0.20980 & 70.3 & 0.34920 & 52.3 & 0.39680 & 48.5 & 0.51190 & 38.6 \\
\hline 150 & 0.16990 & 76.0 & 0.27710 & 62.2 & 0.32900 & 57.3 & 0.40040 & 52.0 \\
\hline 200 & 0.12910 & 81.7 & 0.19630 & 73.2 & 0.25000 & 67.5 & 0.31920 & 61.7 \\
\hline 250 & 0.06920 & 90.2 & 0.13950 & 81.0 & 0.16940 & 78.0 & 0.20970 & 74.8 \\
\hline
\end{tabular}




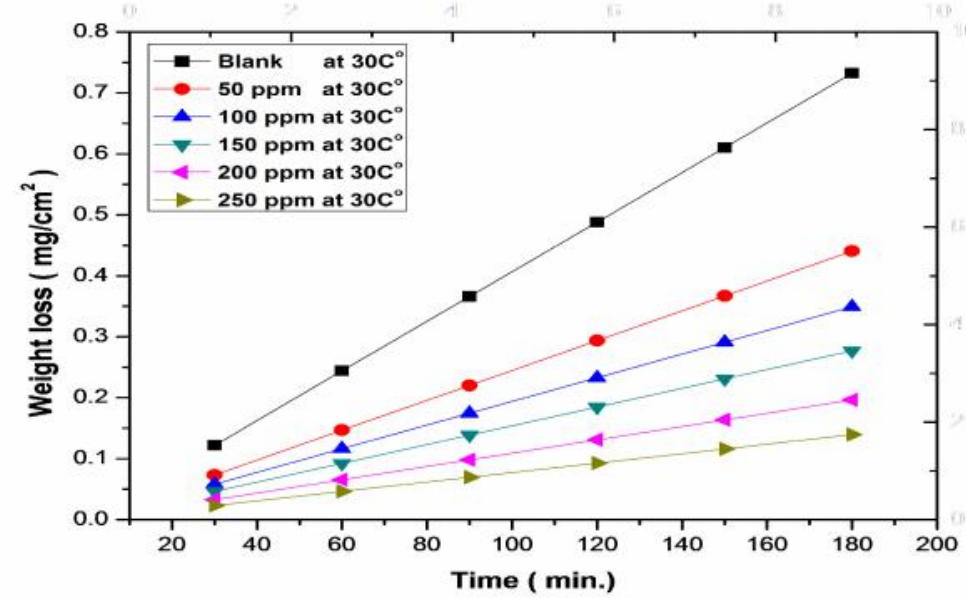

Figure 1 - Weight loss-time curves for the corrosion of the galvanized iron in sulfide polluted salt water in absence and presence of satirn at temperatures $30^{\circ} \mathrm{C}$

\subsection{1- Effect of Temperature}

The temperature effect on the corrosion parameters of the galvanized iron with the addition of satirn was studied using weight loss technique. According to the data of the Table 1, the corrosion rate of the galvanized iron increases with the increase of the temperature, the inhibition efficiency of satirn decreased Fig. 2. This suggested to the possibility of the desorption of the desorbed inhibitor molecules on the metal surface with the increase of the temperature. This behavior shows that the addition of the inhibitor is physically on the metal surface. Arrhenius-type dependence is a rela- tion between corrosion rate and temperature like in Eq. (2):

$$
k=A e^{\left(-E^{*} a / R T\right)}
$$

where $k$ is the corrosion rate, $E_{a}^{*}$ is the apparent activation energy, $R$ is the universal gas constant, $T$ is the absolute temperature, and $A$ is the frequency factor. Fig. 3 is Arrhenius plot (log $k$ against the reciprocal of temperature $(1 / T))$ for the galvanized iron in $3.5 \% \mathrm{NaCl}$ and $16 \mathrm{ppm} \mathrm{Na}_{2} \mathrm{~S}$ in absence and presence of different concentrations of Satirn. Straight lines of high correlation coefficients were obtained.

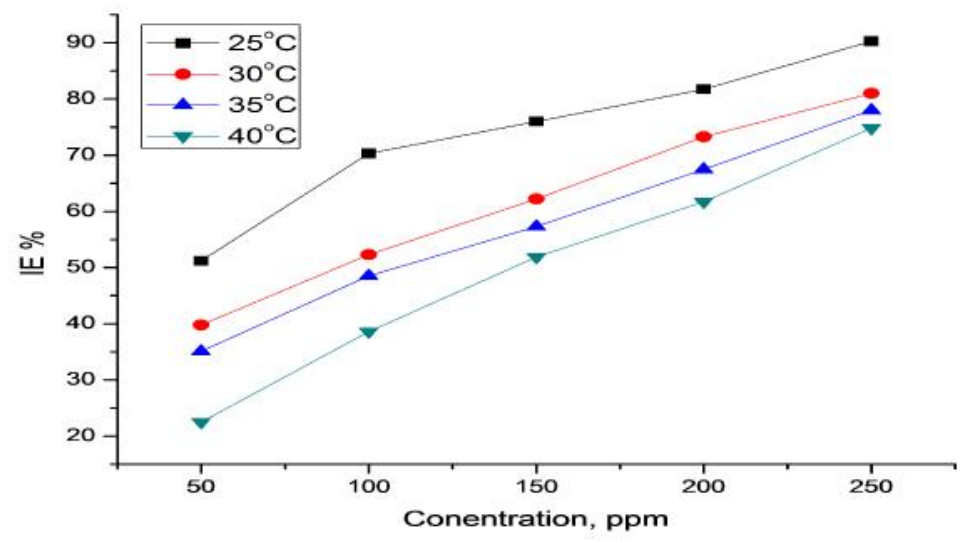

Figure 2 - The effect of inhibitor concentration and temperature on the inhibition efficiency of satirn

The values of activation energy, $\mathrm{E}_{\mathrm{a}}{ }^{*}$ were 8.50 , $55.49 \mathrm{k} \mathrm{J} \mathrm{mol}^{-1}$ for the blank and in the presence of Satirn, respectively. The increase in the activation energy is directly proportional to satirn concentration, indicating that the energy barrier for the corrosion process is also increased [8]. An alternative formulation of Arrhenius equation is [9]:

$$
k=R T / N h \exp \left(S^{*} / R\right) \exp \left(-H^{*} / R T\right)
$$

where $\mathrm{h}$ is the Planck's constant and $\mathrm{N}$ is the Avogadro's number. Fig. 4 shows a plot of $\log \mathrm{k} / \mathrm{T}$ as a function of $1 / T$ for galvanized iron. Straight lines were obtained with a slope of $-\mathrm{H}^{*} / \mathrm{R}$ and an intercept of In R/Nh $+S^{*} / R$ from which the values of $\mathrm{H}^{*}$ and $\mathrm{S}^{*}$ were calculated for the blank and Satirn. The values of the activation enthalpy, $\mathrm{H}^{*}$ were 7.1 and $33.5 \mathrm{~kJ} \mathrm{~mol}^{-1}$ and the values of the activation entropy, $S^{*}$ were $-135.1-, 272.5 \mathrm{~J}$ $\mathrm{mol}^{-1} \mathrm{~K}^{-1}$ for the blank and satirn, respectively. It known that values of $\mathrm{H}^{*}$ lower than $41.9 \mathrm{~kJ} \mathrm{~mol}^{-1}$ indicative of physical adsorption [10]. The increase in the activation enthalpy $\left(\mathrm{H}^{*}\right)$ in presence of the inhibitors means that the addition of the satirn to 
$3.5 \% \mathrm{NaCl}$ and $16 \mathrm{ppm} \mathrm{Na}_{2} \mathrm{~S}$ solution increases the height of the energy barrier of the corrosion reaction to the inhibitor depends on the concentration of satirn. The adsorption of satirn molecules on the metal surface leads to a lower number of hydrogen atoms adsorbed on it; this will cause a decrease in hydrogen evolution rate rather than the rate of metal dissolution, because of the blocking of the surface of the metal by the inhibitor molecules.

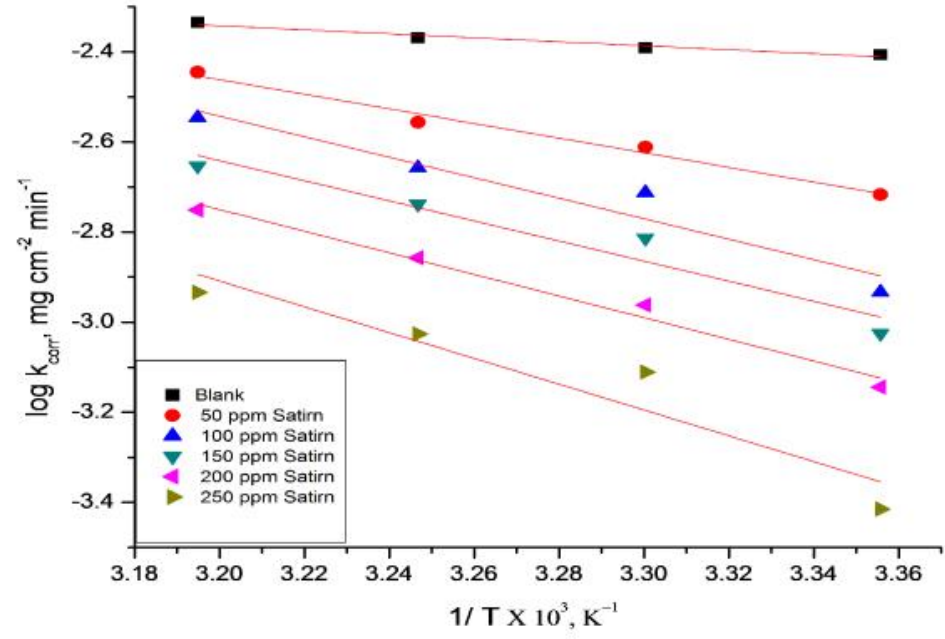

Figure 3 - Arrhenius plots for the corrosion rate of the galvanized iron in sulfide polluted salt water in absence and presence of satirn at different temperatures

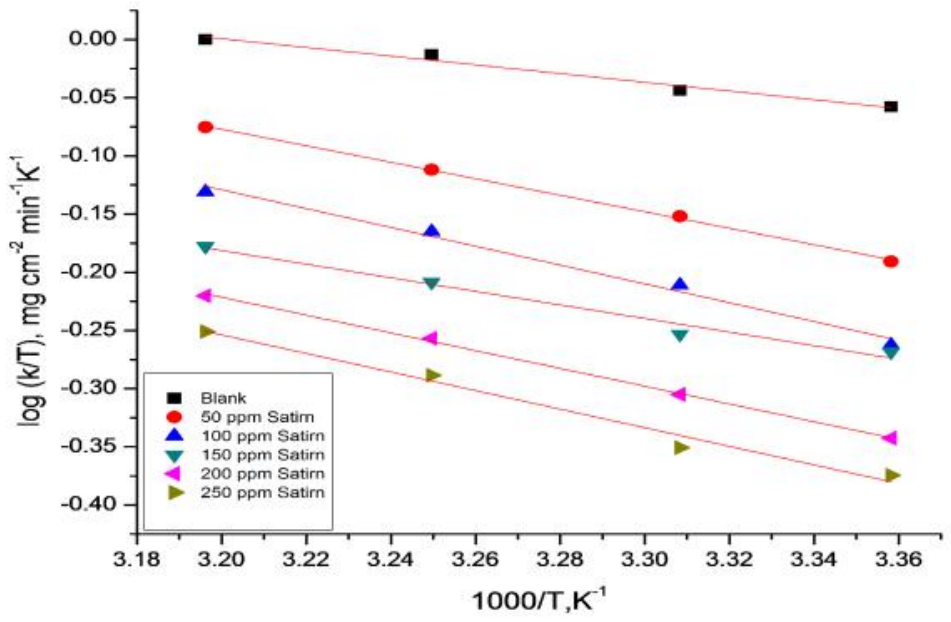

Figure 4 - $\log (k / T)$ versus $1 / T$ for the galvanized iron in sulfide polluted salt water in absence and presence of satirn at different temperature

\subsection{2- Adsorption isotherm}

Basic information on the interaction between the inhibitor and the galvanized iron can be provided by the adsorption isotherm. The adsorption of the inhibitors can be described by two main types of interaction: physical adsorption and chemisorptions [11-15]. These are influenced by the chemical structure of the inhibitor, the type of the electrolyte, and the charge and nature of the metal. The surface coverage of the metal surface by the adsorbed inhibitor was calculated assuming no change in mechanism of the cathodic reaction using the equation:

$$
=\left[1-\left(W_{2} / W_{1}\right)\right]
$$

where $i_{b}$ corr and $i_{i}$ corr are the current densities in the presence and absence of the inhibitor. The va- lues for different inhibitor concentrations at different temperatures were tested by fitting to various isotherms. By far the best fit was obtained with the Temkin isotherm. Temkin isotherm:

$$
a=\ln K_{a d s} C
$$

where $\mathrm{a}$ is heterogeneity factor, $\mathrm{C}$ is the concentration of the inhibitor, and $K_{a d s}$ is the adsorption equilibrium constant, which is related to the standard free energy of adsorption ( $\mathrm{G}^{\circ}$ ads ) by the equation:

$$
\text { Kads }=(1 / 55.5) \exp (- \text { Goads } / R T)
$$

where 55.5 is the concentration of water in $\mathrm{mol} / \mathrm{L}$ at metal solution interface. The plot of surface coverage ( ) as a function of logarithm of satirn concentration at the studied temperatures is shown in Fig.5. 


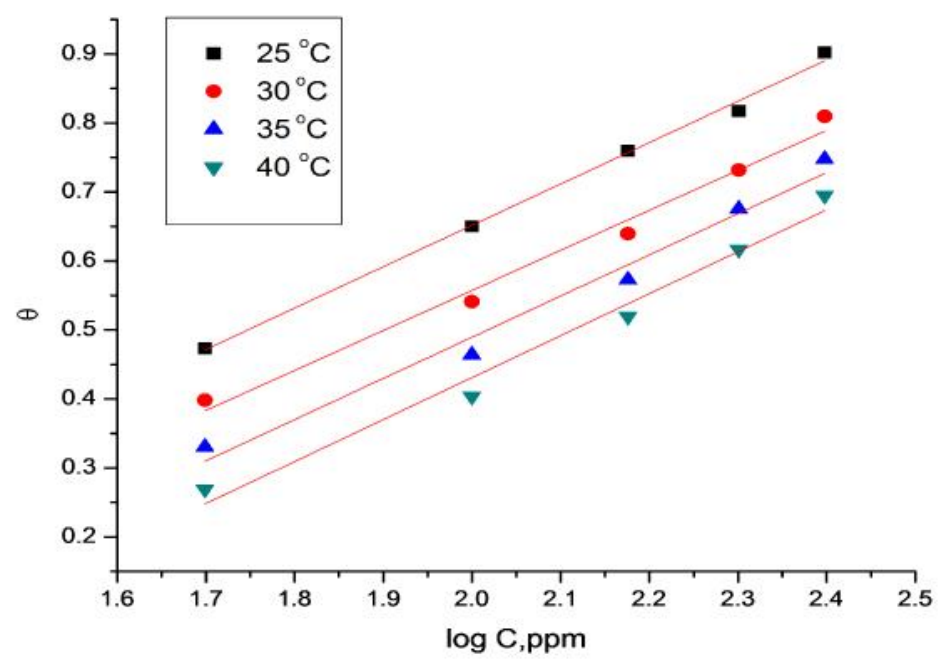

Figure 5 - Temkin adsorption isotherm for satirn at different temperatures for the galvanized iron in sulfide polluted salt water

From the plot, straight lines were obtained for satirn indicating that the experimental data fit well into Temkin adsorption isotherm at all studied temperatures. The Temkin isotherm characterizes the chemisorptions of uncharged molecules on heterogeneous surface [16]. The values of $\mathrm{K}_{\mathrm{ads}}$ decrease with increasing temperature, suggesting that the inhibitor is physically adsorbed on the galvanized iron surface. Generally, $\mathrm{K}_{\mathrm{ads}}$ denotes the strength between adsorbate and adsorbent. The $\mathrm{G}^{\circ}{ }^{\circ}$ ads values were calculated from this plot were negative this mean spontaneous adsorption of the inhibitor molecules on the surface of the galvanized iron. The heat of adsorption ( $\mathrm{H}^{\circ}$ ads) can be calculated according to the Vant Hoff's:

$$
\log K_{a d s}=\left(-H_{a d s}^{\circ} / 2.303 R T\right)+\text { constant }
$$

In order to calculate heat of adsorption ( $\mathrm{H}^{\circ}{ }^{\circ}$ ads), $\log K_{a d s}$ was plotted against 1000/T Fig.6. A straight line was obtained. The absolute values of
$\mathrm{H}^{\circ}$ ads obtained in this study was lower than $100 \mathrm{~kJ}$ $\mathrm{mol}^{-1}$, this indicative of physisorption, and this support the above mechanism of adsorption. The negative value of $\mathrm{H}^{\circ}$ ads $\left(-46.1 \mathrm{~kJ} \mathrm{~mol}^{-1}\right)$ in the presence of the inhibitor reflects the exothermic nature of galvanized iron dissolution process. It is clear that the activation enthalpy vary in the same manner as the activation energies, supporting the proposed inhibition mechanism. According to the basic equation:

$$
G_{\text {ads }}^{o}=H_{\text {ads }}^{\circ}-T S_{\text {ads }}^{o}
$$

The entropy of adsorption, $\mathrm{S}_{\text {ads }}^{0}$ was calculated. Large and negative values of entropies imply that the activated complex in the rate determining step represents an association rather than dissociation step, meaning that a decrease in disordering takes place on going from reactant to the activated complex.

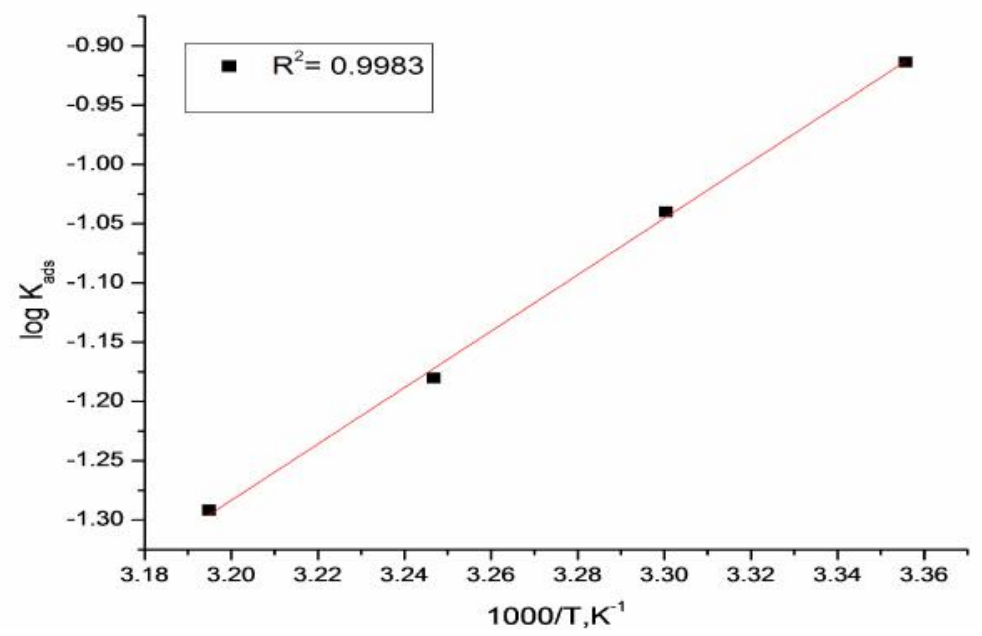

Figure 6 - Log $K_{a d s} v s$ 1000/T for the corrosion of the galvanized iron in presence of satirn 


\subsection{Polarization measurements}

Potentiodynamic anodic and cathodic polarization were carried out at $25^{\circ} \mathrm{C}$ in $3.5 \% \mathrm{NaCl}$ and 16 ppm $\mathrm{Na}_{2} \mathrm{~S}$ in the absence and presence of different concentrations of the inhibitor are shown in Fig.7.
From the figure, both anodic and cathodic currents were inhibited by the increase of the inhibitor concentration. From this result the addition of the inhibitor decreases the metal dissolution at the anode and the hydrogen evolution reaction at the cathode.

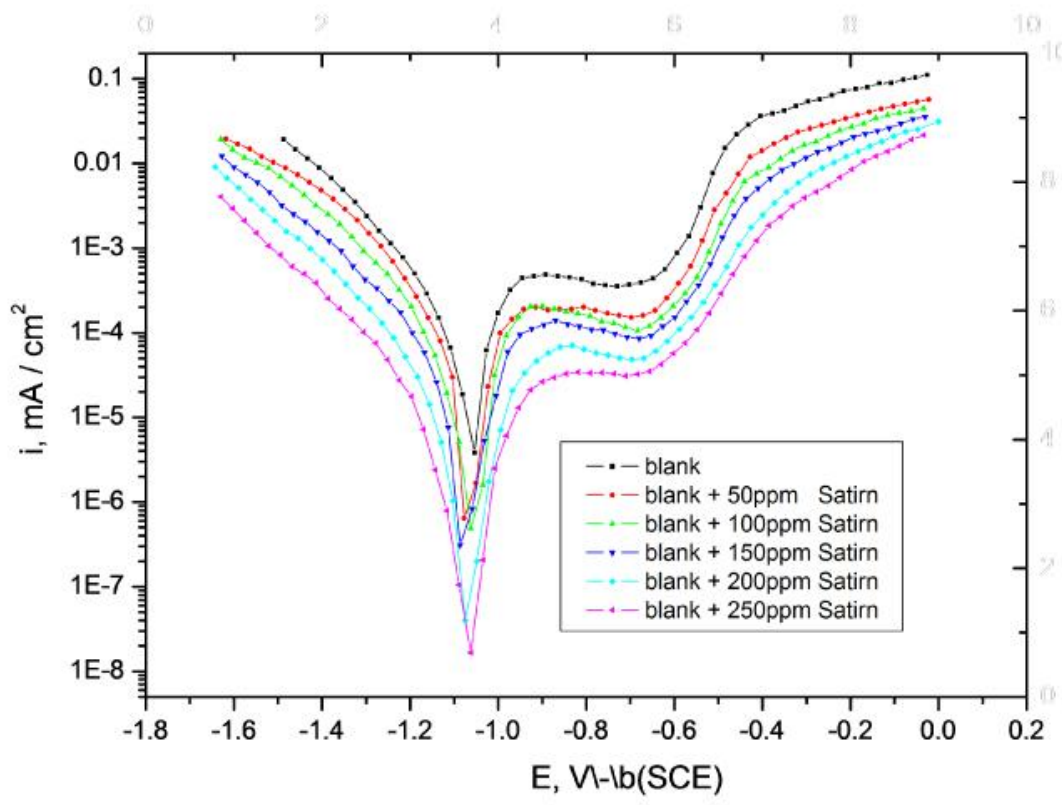

Figure 7 - Potentiodynamic polarization curves for the corrosion of the galvanized iron in sulfide polluted salt water in the absence and presence of different concentrations of satirn at $25^{\circ} \mathrm{C}$

Table 2 shows the values the corrosion potential $\mathrm{E}_{\text {corr }}$, corrosion current density $\mathrm{i}_{\text {corr }}$, Tafel slopes $\left(\beta_{\mathrm{a}}\right.$ and $\left.\beta_{\mathrm{c}}\right)$, and the inhibition efficiency for the tration of the inhibitor. The values of $i_{\text {corr }}$ were estimated by Tafel extrapolation of cathodic and anodic curves to open circuit corrosion potential. corrosion of galvanized iron with different concen-

Table 2 - The effect of concentration of satirn on the electrochemical parameters calculated by using potentiodynamic technique for corrosion of galvanized iron in sulfide polluted salt water at $25^{\circ} \mathrm{C}$

\begin{tabular}{|c|c|c|c|c|c|c|c|}
\hline $\begin{array}{c}\text { Conc., } \\
\text { ppm }\end{array}$ & $\begin{array}{c}\text { Ecorr, V vs } \\
\text { SCE }\end{array}$ & $\begin{array}{c}\text { icorr, } \mu \mathrm{A} \\
\mathrm{cm}-2\end{array}$ & $\begin{array}{c}-\beta \mathrm{C}, \\
\mathrm{mV} \mathrm{dec}-1\end{array}$ & $\begin{array}{c}\beta \mathrm{\beta a}, \\
\mathrm{mV} \text { dec-1 }\end{array}$ & $\begin{array}{c}\mathrm{C} . \mathrm{R} \\
\mathrm{mm} \mathrm{y}-1\end{array}$ & & $\% \mathrm{IE}$ \\
\hline blank & 1.056 & 11470 & 265 & 209 & 133.19 & ------ & ----- \\
\hline 50 & 1.084 & 3622 & 254 & 188 & 42.06 & 0.684 & 68.4 \\
\hline 100 & 1.146 & 2109 & 247 & 176 & 24.48 & 0.816 & 81.6 \\
\hline 150 & 1.152 & 1718 & 240 & 154 & 19.94 & 0.850 & 85.0 \\
\hline 200 & 1.124 & 1516 & 233 & 131 & 17.60 & 0.868 & 86.8 \\
\hline 250 & 1.104 & 1069 & 229 & 128 & 12.41 & 0.907 & 90.7 \\
\hline
\end{tabular}

From this table, it can be concluded that:

- The $\mathrm{i}_{\text {corr }}$ values decrease with the increase of the inhibitor concentration.

- The change in $\beta_{\mathrm{a}}$ from $278-248 \mathrm{mV} \mathrm{dec}^{-1}$ with the increase in inhibitor concentration indicating that the dissolution of the galvanized iron is kinetics in nature.

- The change in $\beta_{\mathrm{c}}$ from $241-210 \mathrm{mV} \mathrm{dec}^{-1}$ with the increase in inhibitor concentration indicating to the hydrogen evolution reaction [17].
- The values of inhibitor efficiency increase with the increase of the inhibitor concentration reaching to a maximum value $90.7 \%$ at $250 \mathrm{ppm}$

- Satirn is a mixed type inhibitor.

The values of inhibition efficiency percentage $\% \mathrm{IE}$ and the degree of surface coverage at each concentration was calculated using the equation $[18,19]$ :

$\% I E=\times 100=[1-($ icorr $($ inh $) /$ icorr $)] \times 100$ 
where $\mathrm{i}_{\text {corr }}$ and $\mathrm{i}_{\text {corr(inh) }}$ are the corrosion current densities of uninhibited and inhibited solution, respectively.

An inspection of the results obtained from Table 2 reveals that, by increasing the inhibitor concentration, the cathodic and anodic current densities decrease by decreasing the metal dissolution at the cathode and the hydrogen evolution at the anode which appears from the table that $\beta_{c}>\beta_{a}$, this is due to presence of donor atoms of the oxygen, electron clouds of the benzene rings, and also the bulky group of the inhibitor making strike hindrance at the metal surface for the reach of the corrosive media to the metal surface.

\subsection{Electrochemical impedance spectroscopy (EIS) measurements}

Figure 7 shows the Nyquist plot of galvanized iron in $3.5 \% \mathrm{NaCl}$ and $16 \mathrm{ppm} \mathrm{Na}_{2} \mathrm{~S}$ in the absence and presence of different concentrations of investigated compound was investigated by EIS method at $25^{\circ} \mathrm{C}$ after $30 \mathrm{~min}$ immersion. All the impedance spectra were measured at the corresponding opencircuit potentials. The charge-transfer resistance $\left(R_{c t}\right)$ values were calculated from the difference in impedance at lower and higher frequencies, as suggested [20]. The double-layer capacitance $\left(\mathrm{C}_{\mathrm{dl}}\right)$ and the frequency at which the imaginary component of the impedance is maximal $\left(-Z_{\max }\right)$ are found as represented in the following equation:

$$
C_{d l}=\frac{1}{2 \pi f_{\max } R_{t}}
$$

where $f_{\max }$ is maximum frequency at which the imaginary component of the impedance $\left(Z_{i m}\right)$ is maximum at $R_{c t}$ is diameter of the loop. Nyquist plots for the galvanized iron in $3.5 \% \mathrm{NaCl}$ and 16 ppm $\mathrm{Na}_{2} \mathrm{~S}$ at various concentration of satirn is presented in Fig.8. Table 3 gives values of charge transfer resistance, $R_{c t}$ double-layer capacitance, $\mathrm{C}_{\mathrm{dl}}$, and $\mathrm{f}_{\max }$ derived from Nyquist plots and inhibition efficiency, the inhibition efficiency got from the charge-transfer resistance is calculated by the following relation:

$$
\% \text { IEct }=\left[1-\left(R^{\prime} c t / R c t\right)\right] \times 100
$$

$\mathrm{R}_{\mathrm{ct}}$ and $\mathrm{R}_{\mathrm{ct}}$ c are the charge-transfer resistance values without and with inhibitor, respectively.

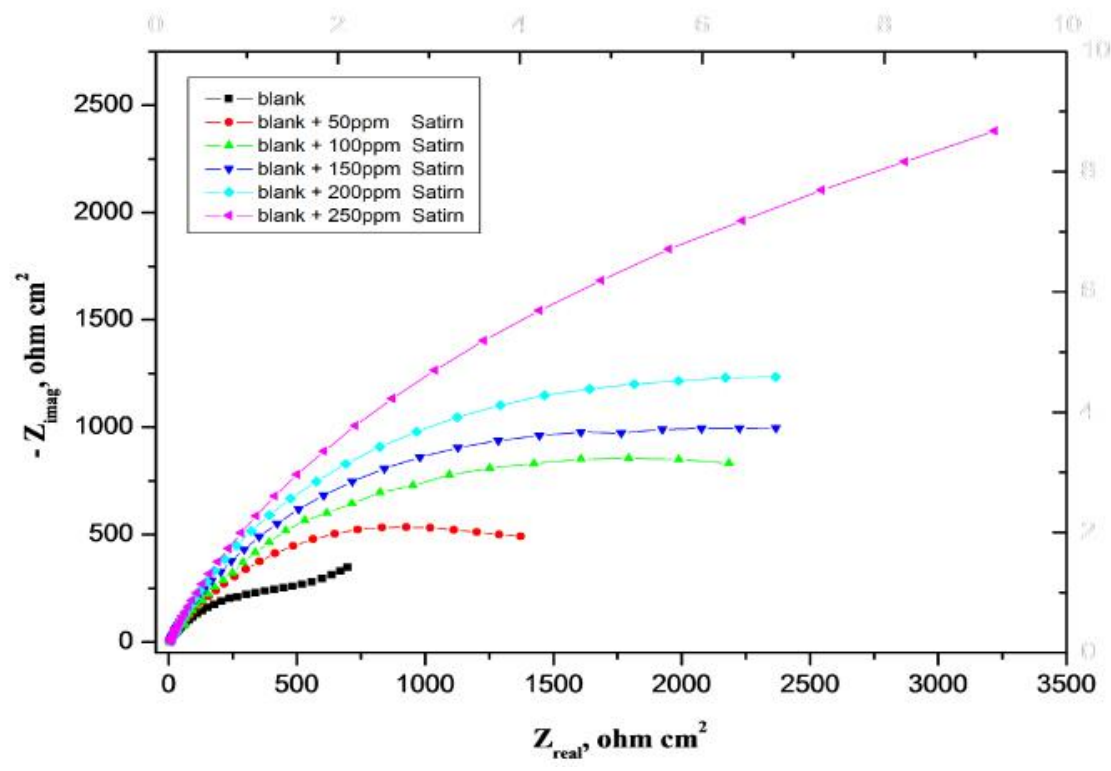

Figure 8 - Nyquist plots recorded for the galvanized iron in sulfide polluted salt water in the absence and presence of different concentrations of satirn at $25^{\circ} \mathrm{C}$

From Fig. 8 the impedance spectra exhibit one single depressed semicircle, and the diameters of semicircle increase with the inhibitor concentration. The single semicircle explains that the inhibition takes place by the diffusion of the charge transfer on the metal surface. Table 3 shows that $R_{c t}$ values increase with inhibitor concentration and consequently the inhibition efficiency increase to $89.3 \%$ at $250 \mathrm{ppm}$. The decrease in $\mathrm{C}_{\mathrm{dl}}$ is due to adsorption of inhibitor molecules by diffusion on the metal surface through the pure geometric blocking of the electrode surface. The linear decrease of $C_{d l}$ with the surface coverage means that the capacitance contribution from the inhibitor-covered surface is solely due to the flat-adsorbed molecules at low surface coverage [21]. 
Table 3 - Electrochemical kinetic parameters obtained by EIS technique for the corrosion of galvanized iron using satirn as inhibitor in sulfide polluted salt water at $25^{\circ} \mathrm{C}$

\begin{tabular}{|c|c|c|c|c|c|c|}
\hline $\begin{array}{c}\text { Conc., } \\
\text { ppm }\end{array}$ & $\begin{array}{c}\mathrm{R}_{\mathrm{s}} \\
\mathrm{cm}^{2}\end{array}$ & $\begin{array}{c}\mathrm{C}_{\mathrm{dll}} \\
\mu^{-1} \mathrm{~cm}^{-2}\end{array}$ & $\mathrm{n}$ & $\begin{array}{c}\mathrm{R}_{\mathrm{t}} \\
\mathrm{cm}^{2}\end{array}$ & $\theta$ & $\% \mathrm{IE}$ \\
\hline blank & 1.294 & 605.5 & 0.886 & 268 & ---- & ---- \\
\hline 50 & 1.210 & 581.4 & 0.873 & 800 & 0.665 & 66.5 \\
\hline 100 & 1.174 & 452.3 & 0.858 & 1300 & 0.794 & 79.4 \\
\hline 150 & 1.124 & 423.6 & 0.874 & 1600 & 0.833 & 83.3 \\
\hline 200 & 1.155 & 374.5 & 0.841 & 1830 & 0.854 & 85.4 \\
\hline 250 & 1.143 & 352.3 & 0.839 & 2290 & 0.883 & 88.3 \\
\hline
\end{tabular}

\subsection{Electrochemical frequency modulation (EFM) measurements}

Intermodulation spectra obtained from EFM measurements are presented in Fig. $(9 a-b)$ as examples of galvanized iron in absence and presence of $250 \mathrm{ppm}$ satrin as a pesticide inhibitor at $25^{\circ} \mathrm{C}$. Each spectrum is a current response as a function of frequency. The two large peaks are the response to the $2 \mathrm{~Hz}$ and $5 \mathrm{~Hz}$ excitation frequencies. These peaks are used by the EFM 140 software package to calculate the corrosion current and Tafel constants.

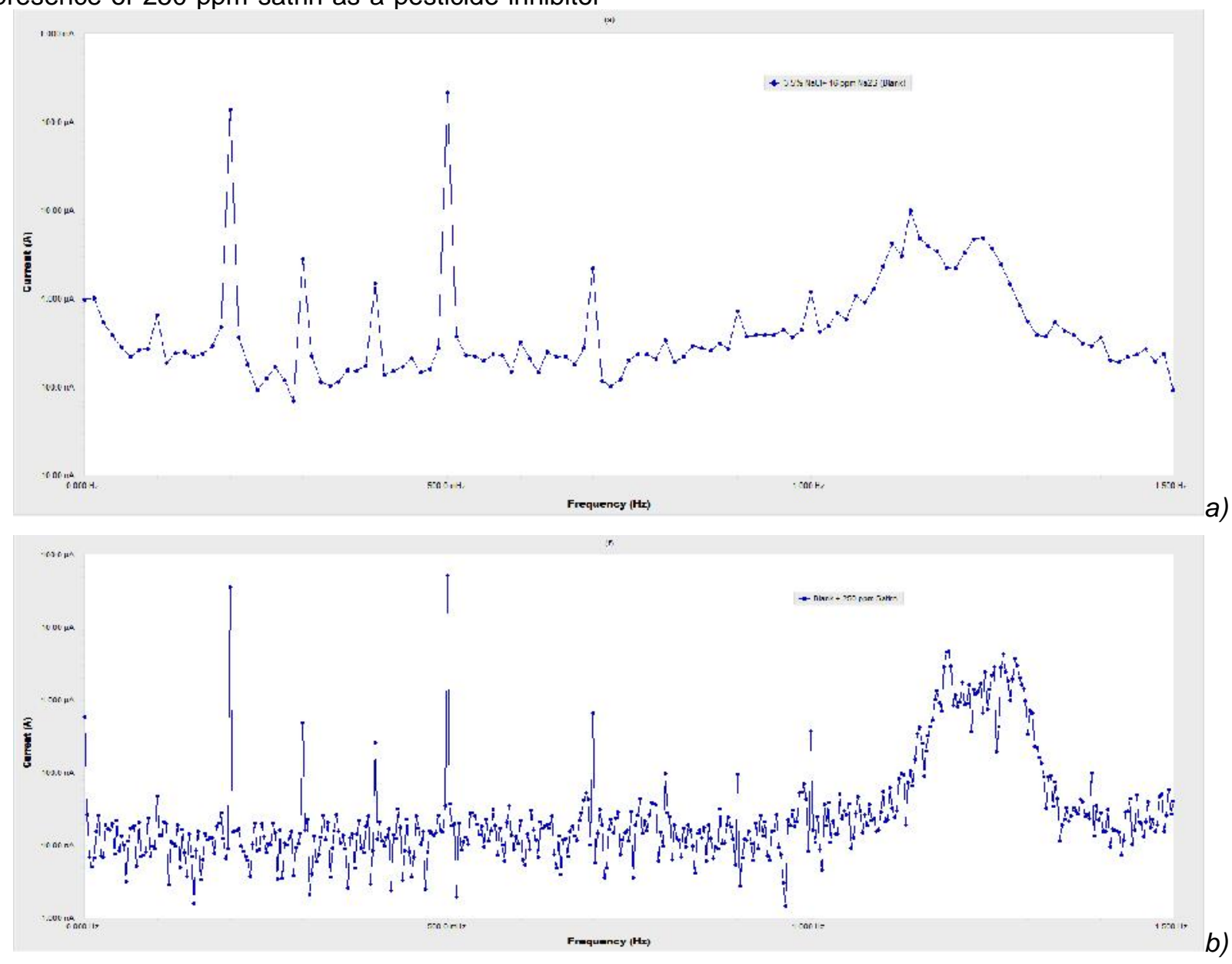

Figure $9 a, b$ - Intermodulation spectrum for the galvanized iron in in sulfide polluted salt water in the absence and presence of $250 \mathrm{ppm}$ of satirn at $25^{\circ} \mathrm{C}$

The calculated corrosion kinetic parameters at different concentrations of the inhibitor in 3.5\% $\mathrm{NaCl}$ and $16 \mathrm{ppm} \mathrm{Na}_{2} \mathrm{~S}$ containing different con- centrations of inhibitor at $25^{\circ} \mathrm{C}\left(i_{\text {corr }}, \beta_{\mathrm{a}}, \beta_{\mathrm{c}}, \mathrm{CF}-2\right.$, CF-3 and \% IE) are given in Table 4. 
Table 4 - Electrochemical Kinetic parameters obtained by EFM technique for galvanized iron in 3.5\% $\mathrm{NaCl}+16 \mathrm{ppm} \mathrm{Na} \mathrm{N}_{2} \mathrm{~S}$ alone and with different concentrations of satirn at $25^{\circ} \mathrm{C}$

\begin{tabular}{|c|c|c|c|c|c|c|c|c|}
\hline \% IE & & $\begin{array}{c}\text { C.R, } \\
\mathrm{mmY}\end{array}$ & CF-3 & CF-2 & $\begin{array}{c}\beta_{\mathrm{c},}, \\
\mathrm{mV} \mathrm{dec}^{-1}\end{array}$ & $\begin{array}{c}\beta_{\mathrm{a},} \\
\mathrm{mV} \mathrm{dec}^{-1}\end{array}$ & $\begin{array}{c}\mathrm{i}_{\text {corr., }} \\
\mu \mathrm{A} \mathrm{cm}^{-2}\end{array}$ & Conc., ppm \\
\hline---- & ----- & 140.31 & 2.85 & 1.85 & 241 & 278 & 13540 & blank \\
\hline 67.38 & 0.6738 & 43.77 & 2.70 & 1.77 & 238 & 273 & 4417 & 50 \\
\hline 80.76 & 0.8076 & 27.00 & 2.64 & 1.82 & 232 & 267 & 2605 & 100 \\
\hline 84.66 & 0.8466 & 21.52 & 2.76 & 1.88 & 228 & 262 & 2077 & 150 \\
\hline 86.12 & 0.8612 & 19.47 & 2.88 & 1.83 & 218 & 253 & 1879 & 200 \\
\hline 89.81 & 0.8981 & 14.30 & 2.91 & 1.76 & 210 & 248 & 1380 & 250 \\
\hline
\end{tabular}

The corrosion current densities obtained from Table 4 are decreasing by increasing the concentration of the inhibitor and hence the inhibition efficiencies increase. The causality factors in Tables 4 are very close to theoretical values which according to EFM theory should guarantee the validity of Tafel slope and corrosion current densities. Values of causality factors in Table 4 indicate that the measured data are of good quality [22]. The standard values for CF-2 and CF-3 are 2.0 and 3.0, respectively. The obtained results showed good agreement of inhibition efficiency obtained from the potentiodynamic polarization, EIS and EFM methods.

\subsection{Biological effect of satirn on escherichia coli}

From the bacterial agriculture of escherichia coli in absence and presence of satirn pesticide inhibitor, we found a small effect on the bacterial

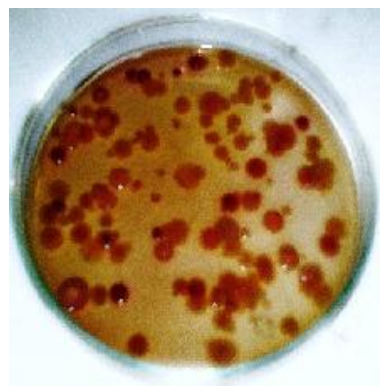

Blank
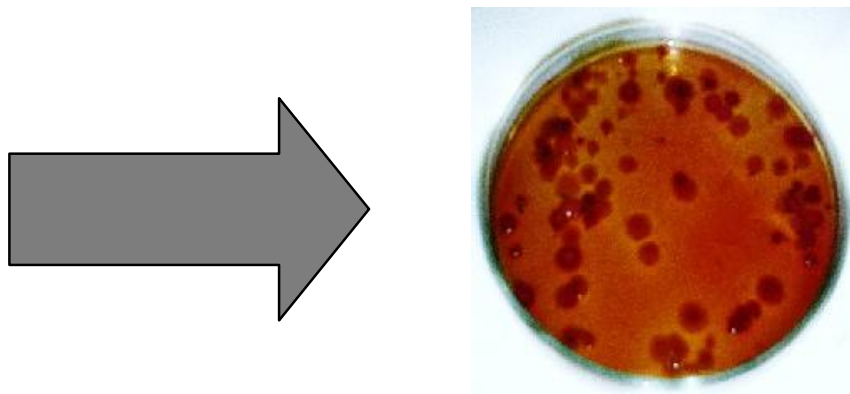

The bacterial agriculture in presence of 250 ppm of satirn activity of escherichia coli according to Table 5 and Fig. 10, which can be controlled by increasing the recycle life of the bacteria in the station. Satirn has oxygen donor atom attached with the proteins and lipids on the bacterial tissues having a little activity for it. So this inhibitor has no toxicity on the bacterial activity, and can be applied safety on the sanitation plants without any problems in the treating operations.

Table 5 - Results obtained from the plate counter for bacterial agriculture

\begin{tabular}{|c|c|c|c|}
\hline CFU (mean) & CFU (R2) & CFU (R1) & Samples \\
\hline $92 \times 10^{4}$ & $95 \times 10^{4}$ & $89 \times 10^{4}$ & Control \\
\hline $83 \times 10^{4}$ & $85 \times 10^{4}$ & $83 \times 10^{4}$ & satirn \\
\hline
\end{tabular}

Figure 10 - The bacterial agriculture in absence and presence of satirn

\subsection{Mechanism of corrosion inhibition}

The isotherm of Fig. 5 characterizes the spontaneous physisorption of phytochemical composition (2.2.1) of satirn on heterogeneous surface [23]. So the mechanism of inhibition of the galvanized iron in $3.5 \% \mathrm{NaCl}$ and $16 \mathrm{ppm} \mathrm{Na} \mathrm{Na}_{2} \mathrm{~S}$ by the phytochemical compounds of satirn explained basically on the adsorption on the metal surface[24] due to the presence of the phytochemical constituents. The adsorption of the inhibitor molecules on the metal surface is due to the donor - acceptor interaction between $\pi$ electrons of donor atoms $\mathrm{O}$ and aromatic rings of inhibitor and the acceptor, i.e., vacant $d$ orbital of iron surface atoms [25]. The inhibitor molecules also can be adsorbed in the form of negatively charged species on the metal surface which can interact electrostatically with positively charged metal surface, leading to increase the surface coverage and consequently protect efficiency even in case of low Satirn concentration. 


\section{CONCLUSIONS}

According to the obtained results, the following conclusions can be drawn:

The satirn pesticide acts as an inhibitor for the corrosion of the galvanized iron in sulfide polluted salt water. The inhibition efficiency increases with increase in the concentration of satirn. The inhibition is due to the adsorption of the inhibitor molecule on the metal surface by charge transfer or by the diffusion of the inhibitor molecules. The adsorption of satirn on the metal surface follows Temkin adsorption isotherm. Values of Tafel constant $\left(\beta_{a}\right.$ and $\beta_{c}$ ) confirm that the inhibitor is a mixed type. Increase in $R_{p}$ and $R_{c t}$ values and decrease in $i_{\text {corr }}$ and $C_{d l}$ values confirm that satirn is adsorbed on the carbon steel surface and inhibition process is followed by monolayer adsorption. The inhibition efficiencies determined by different electrochemical methods are in reasonable good agreement. Thus the satirn was proved to be an effective and low cost inhibitor. This inhibitor has no effect on the biological activity of Escherichia Coli, and can be applying safety on sanitation plants.

\section{REFERENCE}

[1] G. Trabanelli (1991) Inhibitors an old remedy for a new challenge, Corrosion, 47,pp. 410-419.

[2] Ostovari A., Hoseinieh S.M., Peikari M., Shadizadeh S.R., Hashemi S.J., (2009), Corrosion inhibition of mild steel in $1 \mathrm{M} \mathrm{HCl}$ solution by henna extract: $A$ comparative study of the inhibition by henna and its constituents (Lawsone, Gallic acid, $\alpha$-d-Glucose and Tannic acid), Corros.Sci., 51, pp. 1935-1949

[3] Abiola O.K., Otaigbe J.O.E., Kio O.J., (2009) Gossipium hirsutum L. extracts as green corrosion inhibitor for aluminum in $\mathrm{NaOH}$ solution, Corros. Sci., 51, pp. 1879-1881

[4] Muller B., (2002), Corrosion inhibition of aluminum and zinc pigments by saccharides, Corros. Sci., 44, pp. 1583-1591

[5] Abdel-Rehim S.S., Khaled K.F., Abd-Elshafi N.S., (2006), Electrochemical frequency modulation as a new technique for monitoring corrosion inhibition of iron in acid media by new thiourea derivative, Electrochim. Acta, 51, pp. 3269-3277

[6] Bosch R. W., Hubrecht J., Bogaerts W. F., Syrett B.C., (2001), Electrochemical Frequency Modulation: A New Electrochemical Technique for Online Corrosion Monitoring Corrosion, 57, pp. 60-70

[7] Bentiss F, Traisnel M, Chaibi N, Mernari B, Vezin H, Lagrenee M., (2002), 2,5- Bis(n-methoxyphenyl)1,3,4-oxadiazoles used as corrosion inhibitors in acidic media: correlation between inhibition efficiency and chemical structure, Corros. Sci., 44, pp. 2271-2289

[8] Popova, A.; Sokolova, E.; Raicheva, S.; Christov, M., (2003), AC and DC study of the temperature effect on mild steel corrosion in acid media in the presence of benzimidazole derivatives, Corros. Sci., 45, pp. 33-58

[9] Fouda, A. S.; Al-Sarawy, A. A.; Ahmed, F.S.; ElAddasy H. M., (2009), Corrosion inhibition of aluminum 6063 using some pharmaceutical compounds, Corros. Sci., 51, pp. 485-492

[10] Umoren, S. A.; Eduok, U. M.; Solomon, M. M.; Udoh, A. P. (2013) Corrosion inhibition by leaves and stem extracts of Sida acuta for mild steel in $1 \mathrm{M}$ $\mathrm{H}_{2} \mathrm{SO}_{4}$ Solutions investigated by chemical and spectroscopic technique, Arabian Journal of Chemistry, in press

[11] Larabi L., Benali O., Harek Y., (2006), Corrosion Inhibition of Copper in $1 \mathrm{M} \mathrm{HNO}_{3}$ solution by $\mathrm{N}$ Phenyl Oxalic Dihydrazide and Oxalic N-Phenylhydrazide N'-Phenylthiosemicarbazide, Port. Electrochim. Acta, 24, pp. 337-346

[12] Larabbi L., Harek Y., Traisnel M., Mansri A., (2004), Synergistic Influence of Poly(4-Vinylpyridine) and Potassium lodide on Inhibition of Corrosion of Mild Steel in $1 \mathrm{M} \mathrm{HCl}$, J. Appl. Electrochem., 34, pp. 833839

[13] Benali O., Ouazene M., (2011), Inhibition of cold rolled steel corrosion in sulphuric acid solution by 2 mercapto-1-methylimidazole: Time and temperature effects treatments, Arab. J. Chem. 4, pp. 443-448

[14] Larabi L., Benali O., Harek Y., (2007), Corrosion inhibition of cold rolled steel in $1 \mathrm{M} \mathrm{HClO}_{4}$ solutions by $N$-naphtyl $N^{\prime}$-phenylthiourea, Mater. Lett. 61, pp. 3287-3291

[15] Larabi L., Harek Y., Benali O., Ghalem S., (2005), Hydrazide derivatives as corrosion inhibitors for mild steel in $1 \mathrm{M} \mathrm{HCl}$, Prog. Org. Coat. 54, pp. 256 - 262

[16] Fouda A.S., Megahed H.E., Younis T., Abd ElSalam Sh., (2014), Corrosion control of steel in $\mathrm{HCl}$ solutions by cyanoacetamide derivatives, Protection of Metals and Physical Chemistry of Surfaces, 50(2), pp.254-265

[17] Benali O., Larabi L., mekelleche S.M., Harek y., (2006), Influence of substitution of phenyl group by naphthyl in a diphenylthiourea molecule on corrosion inhibition of cold-rolled steel in $0.5 \mathrm{M}$ $\mathrm{H}_{2} \mathrm{SO}_{4}$, J. Mater. Sci. 41, pp. 7064-7073

[18] Ammar, I. A.; Darwish, S. (1967), Effect of some ions on inhibition of the acid corrosion of fe by thiourea, Corros. Sci., 7, pp. 579-596 
[19] Fisher, H. Ann. Univ. Ferrera. Sez. 3 (suppl. 3) (1960) 1.

[20] Tsuru, T., Haruyama, S., Gijutsu, B. J., (1978), Inhibition effect of 3- pyridinecarboxaldehyde thiosemicarbazone (META) on the mild steel corrosion in one Jpn. Soc. Corros. Eng., 27, pp.573-579

[21] Martiez, S., Metikos-Hukovic, M., (2003), A nonlinear kinetic model introduced for the corrosion inhibitive properties of some organic inhibitors, J.Appl. Electrochem. 33, pp. 1137-1142

[22] Ramachandran S., Blanco M., Chen H., Tang W. A., (1996), Self-Assembled Monolayer Mechanism for Corrosion Inhibition of Iron by Imidazolines, Langmuir, 12, pp. 6419-6428
[23] Oguzi E.E., (2007), Corrosion inhibition of aluminum in acidic and alkaline media by Sansevieria trifasciata extract, Corros. Sci., 49, pp. 1527-1539

[24] Larabi L., Benali O., M.Mekelleche S.,Harek Y., (2006), 2-Mercapto-1- methylimidazole as corrosion inhibitor for copper in hydrochloric acid J. Appl. Surf.Sci., 253, pp.1371-1378

[25] Lagrenee M., Mernari B., Bouanis B., Traisnel M., Bentiss F., (2002), Study of the mechanism and inhibiting efficiency of 3,5-bis(4-methylthiophenyl)$4 \mathrm{H}$ - 1,2,4- triazole on mild steel corrosion in acidic media, Corros. Sci., 44, pp. 573-588

\section{IZVOD}

\section{SATIRN KAO PESTICID INHIBITOR ZA KOROZIJU POCINKOVANOG GVOŽĐA U OTPADNIM VODAMA I NJEGOV BIOLOŠKI EFEKAT NA ESCHERICHIA COLI}

Satirn je vrsta pesticida koji je ocenjen kao zeleni inhibitora za koroziju na pocinkovanom gvožđu u slanim rastvorima, što je istraživano hemijskim $i$ elektrohemijskim merenjima. Rezultati polarizacije pokazali su da satirn deluje kao tip mešovitog inhibitora. Ispitivanjima je pronađeno da raste inhibitorno dejstvo sa povećanjem koncentracije satirna do približno $90 \%$ na 250 ppm. Navedenim ispitivanjima je razmatrana adsorpcija stabilnih kompleksa na površini metala. Adsorpcija satirn na površini metala povinuje se Temkinovoj adsorpcijonoj izotermi. Satirn ima blagi uticati na Escherichia coli i može se bezbedno primeniti kod sanitarnih biljka.

Ključne reči: inhibitori korozije, Satirn, pocinkovano gvožđe, slani rastvor

Originalni naučni rad

Primljeno za publikovanje: 11. 09. 2014.

Prihvaćeno za publikovanje: 23. 11. 2014. 